\title{
Managing bushmeat hunting in Okapi Wildlife Reserve, Democratic Republic of Congo
}

\author{
David S. Wilkie, Bryan Curran, Richard Tshombe and Gilda A. Morelli
}

Projected rates of agricultural clearing in the Ituri Forest of north-eastern Democratic Republic of Congo range from 0 to 0.1 per cent per year and suggest that deforestation for subsistence agriculture is not an immediate threat to the integrity of the Okapi Wildlife Reserve (OWR). If the human population continues to grow at over 3 per cent per annum, and bushmeat continues to be a major source of income for rural communities, subsistence-level exploitation of bushmeat may, however, not be sustainable. This paper proposes management approaches that address the demand for and supply of bushmeat, which are targeted at those political districts within the OWR where hunting is the greatest threat to populations of bushmeat species. These management approaches are designed to help conserve the Ituri's natural resources without compromising the health and income security of rural communities.

\section{Introduction}

Concerns about loss of biodiversity in tropical forests have largely focused on the impact of tree felling by loggers, charcoal makers, ranchers or farmers on forest composition, structure and function (Myers, 1980; Barnes, 1990). Because abundance of critical food and shelter tree species declines with tree clearing, loss of habitat is generally seen as the primary cause of reductions in densities of forestdependent animal species. However, recent data have shown that it is not deforestation but defaunation that poses the greatest immediate threat to animal conservation in the forests of the Congo Basin (Behra, 1989; Anstey, 1991; Lahm, 1993; Bennett Hennessey, 1995; Juste et al., 1995; Muchaal and Ngandjui, 1995; Noss, 1995; Njiforti, 1996). Bushmeat hunting for domestic consumption and for the market has the potential to deplete rapidly forest mammal, bird and reptile populations, in some cases to the point of extirpation (Caldecott, 1987; Geist, 1988; Alvard, 1993, 1994; Ludwig et al., 1993; Joanen et al., 1994; Chardonnet et al., 1995; Fitzgibbon et al., 1995).
Bushmeat, particularly in Africa, continues to be an important source of protein for forestdwelling communities and for urban dwellers (Asibey, 1977; ma Mbalele, 1978; Martin, 1983; Anadu et al., 1988; Geist, 1988; Juste et al., 1995). Human populations are believed to be growing at $c$. 3 per cent a year in sub-Saharan Africa and, whereas 20-40 years ago a doubling of population density within isolated forest regions meant a change from one to two people per sq $\mathrm{km}$, now a doubling means a increase from four to eight people per $\mathrm{sq} \mathrm{km}$. As a result, the impact of bushmeat consumption on forest fauna will become more pronounced.

\section{Study area}

The Ituri Forest, in the north-eastern corner of the Democratic Republic of Congo (Figure 1), comprises nearly $65,000 \mathrm{sq} \mathrm{km}$ of tropical moist forest at the edge of the Congo Basin. The area is centred on the upper watershed of the Ituri River, $0-3^{\circ} \mathrm{N}, 27-30^{\circ} \mathrm{E}$. The altitude ranges between 700 and $1000 \mathrm{~m}$, and the 


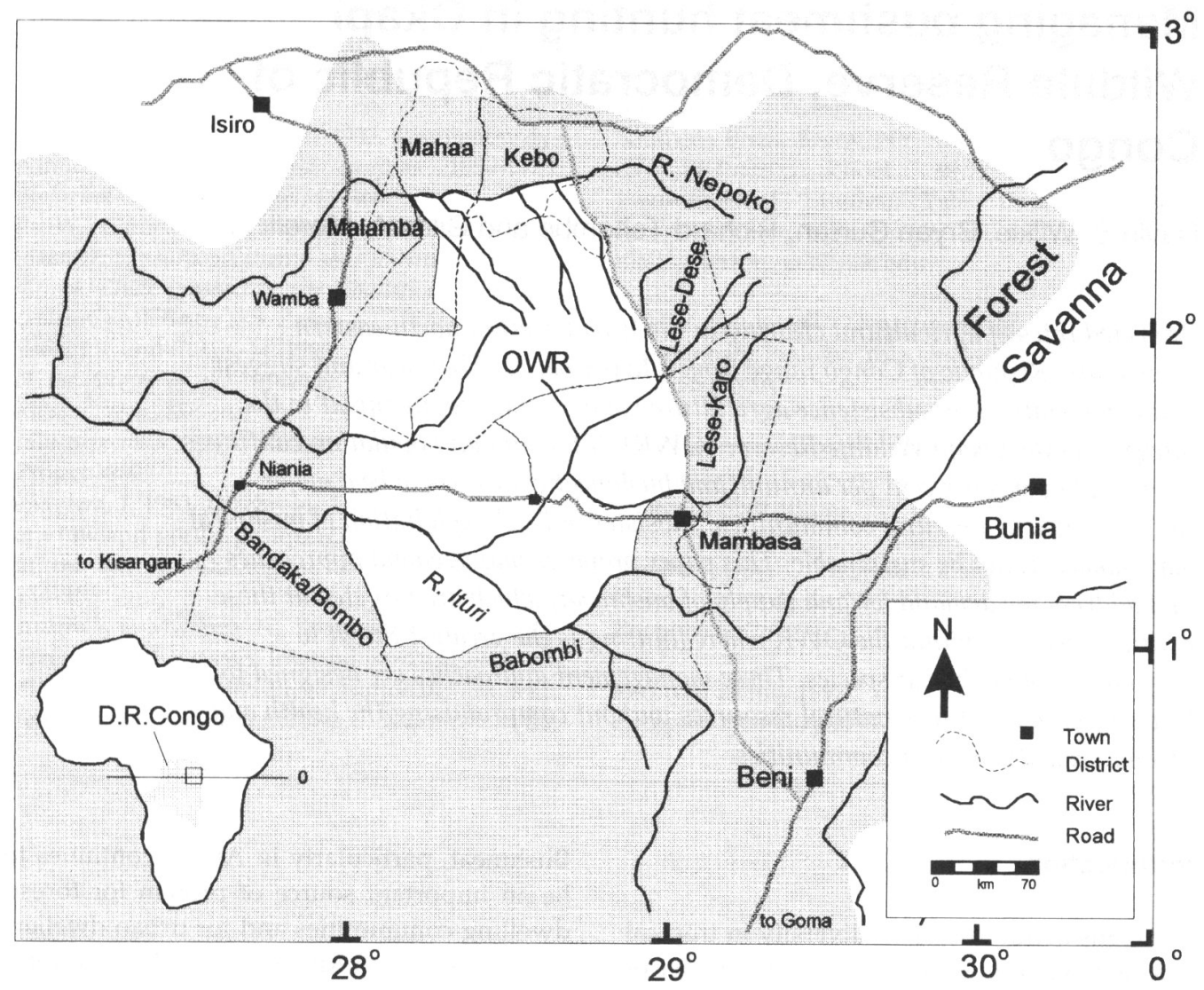

Figure 1. Political districts bordering the Okapi Wildlife Reserve in Ituri Forest, north-eastern Democratic Republic of Congo.

annual rainfall averages about $1900 \mathrm{~mm}$, with a pronounced dry season from December to February. The Ituri is one of the last regions of the Congo basin that still supports relatively large populations of Efe and Mbuti huntergatherers. For at least 1000 years the Ituri has also been home to Bantu and Hamitic farmers. The region is of particular interest for conservation because it probably contains the greatest diversity of mammalian fauna of all forests in the Democratic Republic of Congo (Wilkie and Finn, 1990). Over 90 per cent of the Ituri is intact mature forest (Wilkie, 1990) and is free from the industrial-scale timber operations found elsewhere in the Congo Basin. Almost complete collapse of the infrastructure, an annual inflation rate that often exceeds 1200 per cent, and a decline in world prices for coffee, palm oil and peanuts resulted in the demise of market production of agricultural crops in the Ituri. The Hamitic and Bantu farmers who live in the forest have returned to a barter economy, where crops are produced primarily for subsistence, and bushmeat marketing is now one of the few remaining sources of income. The Efe and Mbuti hunt primarily antelope, primates and rodents, and forage in the forest for honey, tubers and medicinal plants. They obtain over 60 per cent of their calories by trading field labour and forest goods for agricultural crops produced by farmers with whom they have long-term exchange relationships (Bailey and Peacock, 1988). At present, gold prospecting, deforestation from non-industrial logging, charcoal production, agricultural clearance and bush- 
meat exploitation by subsistence and market hunters, are the primary proximate factors having an impact on forest resources.

In 1992, nearly 1.4 million ha of tropical forest in north-eastern Democratic Republic of Congo were formally protected as the Okapi Wildlife Reserve (Stephenson and Newby, 1997). Commercial scale deforestation is illegal in the reserve but a zoning plan being prepared will ensure that indigenous communities retain their traditional rights to exploit forest resources within the reserve. To conserve the region's biological resources while ensuring that local communities continue to meet their basic needs and aspirations, the sustainability of resource exploitation by local communities must be assessed and fostered. Without this information effective management policies for the OWR cannot be developed and implemented.

\section{Deforestation}

Wilkie et al. (1997a) estimated the rate of deforestation within the Ituri over the next 40 years using: (i) Landsat imagery to estimate area and distribution of disturbed and mature forest within and bordering the OWR (Table 1); (ii) a 1993-94 household census and national level statistics to estimate human population size and growth rate (3.18 per cent); and (iii) per household agricultural field area (range $0.3-0.7 \mathrm{ha} /$ year) and fallow period (15 years) to calculate the area of land required by farmers for sustainable slash-andburn agriculture.

Land area cleared annually was estimated by multiplying the number of farmer families by the average field size by the number of fields cleared each year per family. We assumed that all adult males were married and had families, so the number of adult male farmers in the census was used as a surrogate for the number of farmer families. We know that farmers clear secondary regrowth (fallow) vegetation if available, rather than incurring the higher labour costs of clearing mature forest (Wilkie and Curran, 1993). We assumed that 10 per cent of the area characterized in the Landsat image mosaic as disturbed vegetation is uncultivable (i.e. too swampy, hilly or sandy), and an additional 0.05 ha per household is used for settlements (Wilkie and Finn, 1988). We also assumed that at time zero the remaining land characterized as disturbed vegetation in the Landsat imagery is evenly divided among vegetation age classes that represent active agriculture and all fallow years up to the maximum fallow period ( $F=$ 15 years). Given these assumptions mature forest will only be cleared if,

$$
(S n+S n \times F) \times H-R \times 0.90-H \times 0.05>0
$$

where $R$ is the area of disturbed (regrowth) forest, $S$ is field size per household per year, $n$ is the number of fields cleared per household per year, $F$ is the fallow period and $H$ is the number of farmer households. The area of mature forest cleared each year is the value of the

Table 1. Area, mature forest cover, demography, bushmeat eaten and field size in Ituri districts in 1994

\begin{tabular}{|c|c|c|c|c|c|}
\hline & $\begin{array}{l}\text { Total area } \\
\text { (ha) }\end{array}$ & $\begin{array}{l}\text { Percentage } \\
\text { mature } \\
\text { forest }\end{array}$ & $\begin{array}{l}\text { Human population } \\
\text { size }\end{array}$ & $\begin{array}{l}\text { Bushmeat eaten } \\
\text { (kg/year) }\end{array}$ & $\begin{array}{l}\text { Annual field area } \\
\text { cultivated per } \\
\text { household (ha) }\end{array}$ \\
\hline Bandaka-Bombo & 535,968 & 93 & 7,861 & 363,952 & 0.48 \\
\hline Babombi & 491,792 & 98 & 6,783 & 333,869 & 0.48 \\
\hline WaLese-Karo & 392,499 & 94 & 5,884 & 279,094 & 0.50 \\
\hline WaLese-Dese & 456,999 & 95 & 2,268 & 109,890 & 0.50 \\
\hline Mahaa & 295,534 & 78 & 2,933 & 140,572 & 0.30 \\
\hline Malamba & 30,549 & 16 & 2,568 & 113,628 & 0.30 \\
\hline Kebo & 119,671 & 94 & 600 & 25,613 & 0.70 \\
\hline Total & $2,323,011$ & 92 & 28,897 & $1,366,617$ & \\
\hline
\end{tabular}


left hand side of the equation when it is positive.

For each year of the simulation, the number of farmer households was increased by the population growth rate $(r=3.18$ per cent), and the relative area of mature and disturbed forest was recalculated based on the area of mature forest cleared that year. Because land cover data were from 1987 and the demographic data were from 1994 we lowered farmer household numbers by the annual growth rate to estimate farmer household number in 1987 -time zero for the deforestation simulation.

Simulation results showed that over 40 years human population increased from less than 30,000 to over 100,000 , and population density rose from 1.3 people/sq $\mathrm{km}$ to over 4.5 people/sq km. Yet, even with this substantial increase in human population density, agricultural-based clearing of intact mature forest within the seven political districts within or bordering the OWR is expected to range only from 0 to 0.1 per cent per year 40 years into the future. Subsistence agriculture was thus considered unlikely to constitute a major concern for forest conservation in the Ituri in the near to mid-term.

Extensive mature forest clearing occurred during the colonial period to establish oilpalm and coffee plantations, particularly in Mahaa and Malamba districts (22 and 84 per cent of mature forest cleared, respectively). Few commercial plantations are still in production and throughout the Ituri most have been abandoned and have become secondary forest, resulting in a relative abundance of suitable land for subsistence agriculture. Fallow forest will be sufficient for agriculture within $15 \mathrm{~km}$ of settlements in four (WaLeseDese, Mahaa, Malamba and Kebo) of the seven districts, and will only become insufficient for the others after 20 or 40 years. Presence of sufficient fallow forest is, therefore, the key to the predicted low rates of mature forest clearing in the Ituri. Even if resident populations increase substantially, ample fallow forest for agriculture will be available for 20-40 years and mature forest

Table 2. Capture ratios of bushmeat species in eastern Congo

\begin{tabular}{|c|c|c|c|c|c|}
\hline \multirow[b]{2}{*}{ Species groups } & \multirow[b]{2}{*}{ Weight (kg) } & \multicolumn{4}{|c|}{ Relative contribution by weight for each hunting method } \\
\hline & & Bow* & Bowt & Netł & Trap§ \\
\hline Duikers and other small antelope & & 0.63 & 0.64 & 0.98 & 0.77 \\
\hline Cephalophus monticola & 4.70 & & & & \\
\hline Cephalophus nigrifrons & 13.90 & & & & \\
\hline Cephalophus leucogaster & 16.70 & & & & \\
\hline Cephalophus callipygus & 17.70 & & & & \\
\hline Cephalophus dorsalis & 22.00 & & & & \\
\hline Cephalophus sylvicultor & 68.00 & & & & \\
\hline Neotragus batesi & 3.80 & & & & \\
\hline Hyemoschus aquaticus & 11.20 & & & & \\
\hline Primates & & 0.17 & 0.24 & 0.00 & 0.00 \\
\hline Cercocebus galeritus & 7.90 & & & & \\
\hline Cercocebus albigena & 7.70 & & & & \\
\hline Colobus pennanti ellioti & 8.20 & & & & \\
\hline Cercopithecus ascanius & 3.60 & & & & \\
\hline Cercopithecus mona & 3.80 & & & & \\
\hline Cercopithecus mitis & 6.00 & & & & \\
\hline Other species & & 0.20 & 0.12 & 0.02 & 0.23 \\
\hline Cricetomys emini & 1.95 & & & & \\
\hline Atherurus africanus & 2.88 & & & & \\
\hline Potamochoerus porcus & 61.0 & & & & \\
\hline
\end{tabular}

Sources: *Wilkie and Curran, 1991; † Harako, 1976; † Ichikawa, 1983; §Wilkie, 1989. 
will continue to cover over 80 per cent of the landscape as long as: (i) markets for commercial crops do not revitalize; (ii) abandoned plantations are not re-established; (iii) farming does not become a major subsistence activity of the majority of foragers; and, (iv) outside immigration does not become a major contributor to population growth (Wilkie et al., 1997a).

\section{Hunting impacts}

In contrast to the potentially optimistic future for mature forest conservation within the Ituri over the next 40 years, the outlook for animal populations is less favourable, particularly within $15 \mathrm{~km}$ of settlements where almost all hunting occurs. Using data on per capita meat consumption ( $159 \mathrm{~g} /$ person/day for foragers; $117 \mathrm{~g}$ /person/day for farmers), relative proportions of different species captured by foragers and farmers according to the hunting method used (Table 2), and human population size, Wilkie et al. (1997a) estimated harvests (consumption) of important bushmeat species within each political district (Table 1). Similarly, total annual production of each bushmeat species within each district was estimated by multiplying the area of the district in hectares by the sum of the individual species's productivity estimates. Animal density, biomass and production figures for the Ituri were drawn from data collected both within and outside Ituri (Hart, 1985; Wilkie and Finn, 1990; Thomas, 1991; White, 1994; Fa et al., 1995). Monodominant Gilbertiodendron dewerrei forest, which occurs in patches primarily in the southern reaches of Ituri, tends to support lower primate densities (Thomas, 1991). This means that categorizing forest only as either disturbed or mature will overestimate primate production and biomass, because most primate density data used were from mixed dominant forest (Thomas, 1991), which covers most of Ituri. The two estimates of duiker densities for the Ituri (Hart, 1985; Wilkie and Finn, 1990) differ by a factor of 5-10. Hart's (1985) estimates were consistently lower than those of Wilkie and Finn (1990) but were based on more reliable drive counts. Wilkie and Finn's data were based on pellet group counts. Potential errors in estimating dung longevity and pellet deposition rates may have resulted in Wilkie and Finn's overestimation of duiker numbers (White, 1994). As a result Wilkie et al. (1997a) used both high (Wilkie and Finn, 1990) and low (Hart, 1985) duiker productivity estimates to assess the sustainability of duiker hunting in Ituri.

Table 3. Percentage of total annual bushmeat production consumed by households living in districts surrounding the Okapi Wildlife Reserve (OWR) in 1994

\begin{tabular}{|c|c|c|c|c|c|c|c|c|}
\hline & \multicolumn{4}{|c|}{ Within $15 \mathrm{~km}$ of settlements } & \multicolumn{4}{|c|}{$\begin{array}{l}\text { Entire area of each district within and } \\
\text { bordering the OWR }\end{array}$} \\
\hline & \multicolumn{2}{|l|}{ Duikers } & \multirow[b]{2}{*}{ Primates } & \multirow[b]{2}{*}{ Others } & \multicolumn{2}{|l|}{ Duikers } & \multirow[b]{2}{*}{ Primates } & \multirow[b]{2}{*}{ Others } \\
\hline & $\begin{array}{l}\text { Low } \\
\text { production }\end{array}$ & $\begin{array}{l}\text { High } \\
\text { production }\end{array}$ & & & $\begin{array}{l}\text { Low } \\
\text { production }\end{array}$ & $\begin{array}{l}\text { High } \\
\text { production }\end{array}$ & & \\
\hline Bandaka-Bombo & 47 & 13 & 0 & 8 & 29 & 8 & 0 & 5 \\
\hline Babombi & 97 & 27 & 0 & 11 & 31 & 8 & 0 & 4 \\
\hline WaLese-Karo & 40 & 11 & 14 & 10 & 26 & 7 & 9 & 7 \\
\hline WaLese-Dese & 26 & 7 & 11 & 6 & 9 & 2 & 4 & 2 \\
\hline Mahaa & 33 & 9 & 0 & 4 & 21 & 6 & 0 & 3 \\
\hline Malamba & 154 & 42 & 0 & 32 & 154 & 42 & 0 & 32 \\
\hline Kebo & 9 & 2 & 0 & 2 & 9 & 2 & 0 & 2 \\
\hline Average & 58 & 16 & 4 & 10 & 40 & 11 & 2 & 8 \\
\hline Total area & 47 & 13 & 4 & 8 & 25 & 7 & 2 & 4 \\
\hline
\end{tabular}

NB Total area refers to production and consumption aggregated across all districts.

(C) $1998 \mathrm{FFI}$, Oryx, 32 (2), 131-144 
If we assume that per capita bushmeat consumption remains stable we predict that bushmeat consumption over 40 years would be expected to rise from 1360 to over 4780 tonnes per year, as human populations triple in size. Even at present levels bushmeat consumption of some species exceeds or is approaching unsustainable levels in the most densely populated districts of the OWR (Wilkie et al., 1997a).

Duikers and other small antelopes account for over 80 per cent of consumption, with over 1100 tonnes being exploited each year at present, rising to over 3800 tonnes by the year 2034. Depending on the production estimates used, the sustainability of duiker exploitation at present levels is ambiguous (Table 3). Duikers are relatively short-lived (7-10 years), and Robinson and Redford (1991) proposed that short-lived species should not be harvested at a rate that exceeds 40 per cent of annual production. In the high duiker density scenario, 16 per cent of duiker production is consumed on average by OWR inhabitants (range 2-42 per cent), and consumption exceeds sustainable harvest rates in one (Malamba) of the seven districts. Using the low duiker density estimates, however, duiker hunting is sustainable in only three districts (average $=58$ per cent, range 9-154 per cent; Table 3).

Primates are hunted primarily in two districts and account for over 26 tonnes of bushmeat consumed each year. Primates are more susceptible to overexploitation by hunters because, according to Robinson and Redford (1991), sustainable harvest rates for long-lived animals should not exceed 20 per cent. Primate hunting within $15 \mathrm{~km}$ of settlements is approaching unsustainable levels (14 per cent) in one of the two districts where hunters specialize in monkey hunting, but it is still well below an unsustainable off-take rate (11 per cent) in the other. Short-lived animals such as rodents appear to be hunted sustainably (2-32 per cent) throughout the OWR (i.e. at rates lower than 60 per cent of production), although they are likely to be heavily exploited in one district.

To examine whether reservoir forest areas that lie more than $15 \mathrm{~km}$ from settlements would be sufficient to restore populations depleted by hunters, Wilkie et al. (1997a) conducted a simulation where production estimates were based on all forest within the region regardless of distance from settlements. Using the high duiker density estimate, 11 per cent of duiker production throughout the forest is consumed on average each year within all political districts, and only one district may be unsustainably exploiting duikers at present. Consumption in all other districts is well below the unsustainable harvest rate (range 2-42 per cent). In stark contrast, in the low density scenario, duiker consumption exceeds 40 per cent of total annual production using aggregated data (range 9-154 per cent). In two districts consumption exceeds 30 per cent of production, and in one district humans consume over 1.5 times the number of duikers that are produced each year. With human populations expected to triple in 40 years the impact of subsistence hunting on duikers will increase. Even when reservoir areas are included and using the high production scenario, duiker exploitation for domestic consumption alone is expected to become unsustainable throughout the OWR within 60 years, assuming that per capita consumption, and methods of management and exploitation remain unchanged.

In areas where bow hunting with poison arrows is important, consumption of primates is on average 2 per cent (range 4-9 per cent) of total annual production. Primate hunting is therefore likely to be sustainable throughout the OWR at present. Harvest rates in one district (WaLese-Karo) may become unsustainable within 20 years when human populations are expected to double.

In the districts that show the highest ratios of consumption to production we might expect a booming trade in bushmeat to meet consumer demand, which will become progressively more difficult to meet by wildlife produced within the district. Thus, restricting the impact of consumption only to within district production is unlikely to reflect the true impact on forest animal populations. The district of Kebo is within trading distance of Mahaa and Malamba. Thus, without field data 
on the extent of market hunting it is impossible to determine whether hunting within the district of Kebo is, in fact, sustainable.

\section{Discussion}

Modelling results from Wilkie et al. (1997a) suggest that at present and over the next 40 years defaunation is a far more critical concern for biodiversity conservation in the OWR than is deforestation for household agriculture. In 40 years the trees may still be standing but the duikers and primates may well be severely depleted in many districts that border the OWR. Deforestation may, however, become an issue if the road system is repaired and markets for timber and agriculture products (primarily coffee and oil-palm) are revitalized (Wilkie and Morelli, 1997).

In contrast to farming's rather limited impact on forest resources, hunting is clearly a concern to long-term conservation of duikers and other small antelope throughout the Ituri, and to primates in the districts where hunters use bows. Modelling results show that even at present, duikers may already be heavily exploited in several districts (Table 3). One can argue that the data on bushmeat consumption patterns and animal densities were collected only in a few areas of the Ituri, and then generalized for the whole forest, thus obscuring any variation that may exist throughout the region. One can also question the accuracy of the production figures. Regardless, the message of the simulation is clear-bushmeat consumption using traditional technologies (bows, nets and snares) poses either an immediate or potential threat to forest animal populations, particularly the duikers and other small antelope species. If hunters adopt more efficient hunting techniques, such as hunting with shotguns and a flashlight or spotlamp, and if markets for bushmeat expand, hunting pressure on bushmeat species within the OWR can only be expected to increase.
Mitigation options that alter the supply of bushmeat

The resource conservation challenges that face the Institut Congolais pour le Conservation de la Nature (ICCN, the Democratic Republic of Congo's protected area management organization) within the OWR are enormous, particularly when it comes to managing bushmeat consumption. Command-and-control measures to curb market hunting may work, at least, en route to major population centres, given enough incorruptible (i.e. very well paid and trained) man-power (Stephenson and Newby, 1997; Wilkie et al., 1997b). Controlling hunting for domestic consumption is, however, likely to be untenable given the size of the area and the importance of bushmeat to the nutrition of forest-dwelling families. Any attempt at de jure control of household bushmeat consumption will probably fail for two reasons: (i) households depend on bushmeat as a nutritional staple and are unlikely to relinquish this without considerable pressure or access to substitutes, and (ii) sufficient repression would require large numbers of trustworthy guards (at one guard per village of 50 people, paid at least $\$$ US1 per day with an additional \$US1 per day for equipment and supplies this would cost over $\$$ US $400,000 /$ year), which no national agency could afford nor international donor be likely to finance. Thus, banning or substantially curbing bushmeat hunting for domestic consumption without providing an acceptable substitute is unrealistic culturally, practically and financially. Furthermore, stopping domestic bushmeat hunting will confirm local fears of infringement on traditional resource use rights expected with establishment of the OWR. This in turn may fuel resentment towards the OWR and may even result in retaliatory hunting of rare and endemic species, and increased elephant poaching.

Establishing a totally protected core area within the OWR as a breeding reservoir may also not be an appropriate strategy for protecting the Ituri's animal populations over either the short or long term. Repressive measures necessary to enforce this would alienate local communities from participating in the process 
of sustainable management of natural resources (Curran and Tshombe, 1997). Furthermore, the 1993-94 population census completed by Curran and Tshombe (1997), and recent forest surveys (J. Hart, pers. comm.) suggest that large areas of the OWR experience minimal human impacts at present; that is, they are already implicitly 'protected'. This de facto protection is for the short to mid-term likely to be as effective as de jure protection. More importantly, the results of the study by Wilkie et al. (1997a) show that even when reservoir areas (core areas) are included in bushmeat production estimates they are insufficient to restore animal populations depleted within the hunting zones. Thus, relying solely on establishing a totally protected core area would not be enough to prevent the overexploitation of forest animal species for bushmeat as human population density increases over time.

In addition, human activity within the reserve is essentially prohibited, although the ICCN has the authority to prohibit or modify the manner in which natural resources of the OWR are exploited. This allows a flexible approach to management, which can respond to changing local conditions. As long as these conditions are regularly monitored, there appears to be little need for further legislation. We agree with Stephenson and Newby (1997) that continued collaboration with local communities in the creation of a zoning system would achieve the same results without causing undue friction between resource users and reserve management.

\section{The special case of bushmeat marketing}

Wilkie et al. (1997a) assessed only the sustainability of hunting for domestic consumption. As the political and economic situation in Democratic Republic of Congo remains unstable and unpredictable, more and more households are turning to bushmeat marketing as a source of income. Open-access resources that are exploited for sale at local, regional or international markets almost always result in the over-exploitation of the resource (Rich, 1960; Bishop, 1972; Trefethen,
1975; Fragoso, 1991; Bodmer, 1995; Chestin and Poyarkov, 1995; Hudson, 1995). Hart and Petrides (1987) showed that commercial bushmeat hunting can be a significant contributor to household livelihoods and results in intensification of forest-animal exploitation. Although no data exist at present to assess the scale of bushmeat hunting throughout the Ituri, regional population centres constitute a huge source of potential or actual demand, and market hunting at any level merely accentuates the impact of hunting for domestic consumption that may already be overexploiting duikers in some areas of the forest.

Unlike hunting for domestic consumption, market hunting is more amenable to command-and-control measures, because as bushmeat is transferred from individual hunters to individual consumers, it is concentrated temporarily by traders who transport the meat from the forest to central markets. Control of market hunting can, therefore, ignore the numerous hunters and consumers, and focus only on the far fewer bushmeat traders. Guards need only set up road-blocks or raid market places on random occasions to enforce bushmeat market regulations. Guards could confiscate bushmeat and fine traders. However, as we suggest below, a bushmeat tax that has an impact on the demand side may be more appropriate and effective.

\section{Mitigation options that alter demand for bushmeat}

Rather than attempting to curb bushmeat production and supply solely with commandand-control measures, mitigation efforts, we believe, should focus more on altering household demand for bushmeat.

One often proposed strategy to reduce demand for bushmeat is to provide domesticated substitutes. Rearing rabbits, brush-tailed porcupines or cane rats is likely to be successful, however, only if the labour and capital costs of production are less than the costs of bushmeat hunting and marketing (i.e. when game is still sufficiently abundant to be worth searching for and transport costs are not prohibitive). Raising small animals has been shown to be viable in periurban areas that are 
close to sources of demand, and where bushmeat species' populations have already been depleted (Lamarque, 1995). Yet, if domestic production of meat only becomes economically viable after wild game has become too scarce to hunt profitably, the strategy is clearly ineffective as a conservation measure. Reducing demand for bushmeat requires therefore, that (i) the price of bushmeat rises relative to alternative sources of meat (assuming that bushmeat demand is elastic), and (ii) alternative sources of meat are produced in sufficient quantity to meet demand at prices comparable to or below that of bushmeat.

Changing the price of bushmeat produced and consumed domestically requires increasing the scarcity of bushmeat (i.e. reducing the supply) or adding a surcharge to the price of bushmeat consumed. This would require fines and bushmeat confiscation targeted at individual households. As demonstrated above this is financially and logistically untenable. Manipulating the supply and price of bushmeat sold at market is, however, more realistic. Although bushmeat could be confiscated at road-blocks or in local markets to increase scarcity, taxing the transportation of bushmeat is likely to be a more effective approach to increasing the price of bushmeat. Taxes should be targeted at bushmeat traders, and set at a price per $\mathrm{kg}$ that is sufficiently high relative to the price of substitutes to result in a decline in demand - e.g. over twice the price differential between bushmeat and chicken sold in urban markets. Bushmeat would not need to be confiscated at roadblocks because, as the costs of taxes are transferred to consumers the price of bushmeat will rise above that of substitutes, driving down demand for bushmeat. Not confiscating bushmeat avoids the need to dispose of the game in a way that (i) does not encourage corruption (assuming that guards are not going to purloin the taxes), and (ii) prevents the sale of confiscated game at reduced prices, thus fuelling demand. As traders' costs increase with taxation (even if guards steal the tax moneys) profits will fall as they attempt to keep rising prices from driving down demand. As demand and profits fall, the price that traders are willing to pay hunters will decline and the income generating incentive for hunting will decline. Setting the bushmeat tax per $\mathrm{kg}$ relatively high attempts to mitigate cultural preferences for bushmeat and consumer willingness to pay a price premium for bushmeat (Steel, 1994). Market prices of bushmeat and domesticated alternatives should be monitored regularly so that the level of taxation can be maintained high enough to curb consumer demand for bushmeat.

Reducing bushmeat sales through taxation may have an adverse impact on local economies dependent on market hunting if, as we expect, consumers switch to buying the meat of domesticated animals. To minimize adverse dietary impacts of a tax on bushmeat, the rate may, initially, have to be set only marginally higher than the differential between domestic animal meat, then increased progressively to provide time for increased production of substitutes. In addition, the costs of transport would make it unlikely that isolated rural communities can market domesticated animals at prices competitive with animals raised closer to centres of demand. To compensate local communities for the loss of revenue-generating opportunities associated with a tax on bushmeat transportation, the portion of taxes remaining after interdiction costs are paid could be returned to the local community in the form of social services, using the Ituri Forest Peoples Fund as a model (IFPF, 1995). Sponsoring social services for local communities with tax revenue is not an attempt to 'teach' local communities the value of limiting bushmeat sales, it is merely using tax revenue as western nations do to provide social amenities. Admittedly, this assumes legal authority and political will to return taxes to local communities, and is not equitable because individual hunters pay the full cost of the tax yet only receive a share in the percentage returned to the community.

In the Ituri, only three areas would need to be monitored to tax the majority of bushmeat being transported to market around the OWR. Keeping to a minimum the number of areas that need to be monitored is particularly important at present because of the almost 
impassable state of the roads. Two teams of 10 guards each would be sufficient to man roadblocks on the roads entering the towns of Mambasa and Wamba. The Nepoko bridge crossing would only require a team of four guards (Figure 1). All three areas are accessible by light plane and by motorcycle. Total cost for monitoring the price of bushmeat and implementing the taxation of bushmeat transport would be around $\$ U S 20,000$ per year assuming \$US1 per day for salaries and \$US1 per day for equipment and supplies. If we assume that 10 per cent of total bushmeat harvested at present is transported to the three regional markets (see Figure 1), that only 20 per cent of all bushmeat transported is detected and taxed, and that the tax per $\mathrm{kg}$ is \$US1-2 (in July 1996 the exchange rate was $35,000 \mathrm{NZ} /$ \$USUS, bushmeat at Dingbo sold for $12,500 \mathrm{NZ}$ per $\mathrm{kg}$ and a $1-\mathrm{kg}$ chicken for $50,000 \mathrm{NZ}$ ), then the tax could raise between \$USUS30,000-60,000 each year, assuming that the guards were honest. Optimistically, a bushmeat tax could fully support the guards and would generate $\$ U S 10,000-40,000$ to be returned to Ituri forest communities each year in social services.

At the same time that policies and practices are implemented to raise the price of bushmeat in the marketplace, it is essential that efforts are made to ensure that substitutes for bushmeat are available. Cane-rat and giant-rat production is possible using domestic food scraps and agricultural waste (Asibey, 1974; Tewe and Ajaji, 1982; Jori et al., 1995). Promoting the production of small domestic animals, such as rabbits, has proved effective in Cameroon in areas where bushmeat was already scarce (HPI, 1996a,b). Small-game raising activities (cane rat, brush-tailed porcupine and bush pig/domestic pig hybrids) to reduce urban demand for bushmeat are also under way in Gabon by Vétérinaires Sans Frontières (funded by the European Union), and as part of the proposed UNDP/GEF project that emphasizes commercial use of forest flora and fauna (Steel, 1994). Raising small domesticated animals such as rabbits is attractive because husbandry and veterinary care are well known. However, consumer tradition and tastes may prefer bushmeat over the meat of domestic animals. Steel (1994) found in Libreville that the average price for the most popular bushmeat species was $\$ U S 3.7 / \mathrm{kg}$ over 1.6 times the price of the most popular cut of beef. This suggests that consumer preference is sufficient to pay a premium for bushmeat, and may make it more worthwhile to focus on small-game rearing (cane rat and giant rat) rather than promoting domestic meat production, at least in the short- to midterm.

Currently, the relative costs and benefits of hunting and of small-domestic-animal raising are poorly understood. We would assume, however, that bushmeat is scarce near population centres. Therefore, animal husbandry should be promoted in periurban areas around Mambasa, Wamba and Epulu in an attempt to lower demand for bushmeat. Technical assistance for pilot game-raising initiatives could be obtained from the Heifer Project (see HPI, 1996a,b), and Vétérinaires Sans Frontières. We believe that to encourage local community adoption of small-animal raising it should be promoted more as a child health and development measure rather than as a game management initiative. To further encourage game raising even if the bushmeat hunting/domestic production cost ratio is tilted toward hunting, the ICCN (in collaboration with donors) could link support of community health or education social services to household adoption of game raising. The annual cost for supporting community-run primary schools and primary health-care clinics is estimated at $\$$ US3000/1000 people per year (IFPF, 1995) - i.e. c. \$US100,000 per year for all communities bordering the OWR. Forest farmers, who are more sedentary than forest foragers, will be the more likely candidates for small-game production, at least initially, and they constitute over 70 per cent of all bushmeat consumers in the Ituri Forest. Encouraging small-animal raising is unlikely to lead to forest clearing for cattle ranching, as has happened in Central and South America, because the occurrence of tsetse fly and associated sleeping sickness makes wooded areas in the Congo Basin unsuitable for cattle raising. 
Small-livestock-rearing pilot projects must be conducted scientifically, where the true costs (in terms of labour and capital) and benefits (in terms of income and nutrition) are compared with those associated with bushmeat consumption. Promotion of these projects in periurban areas will, like bushmeat taxation, disrupt the flow of economic benefits from urban consumers to relatively poor rural producers of bushmeat. Depending on the proportion of rural households involved in bushmeat marketing, and the contribution of bushmeat sales to household income, demand-based approaches to controlling bushmeat hunting may warrant short-term interventions to off-set their adverse impacts on the living standards of rural communities. Small-animal raising should be promoted in the Malamba, Bandaka, Babombi and WaLeseKaro districts. These have the highest bushmeat exploitation levels and are likely to constitute a market for meat exploited in other districts where local demand is lower. The ICCN should also consider pilot small-livestock-raising in the periurban sections of more distant population centres, such as Kisangani, Bunia, Isiro, Butembo and Beni, where demand for bushmeat drives much of the market hunting in Congo's eastern forests.

\section{Management of bushmeat exploitation through local ownership}

Another, often discussed approach to game conservation in developing countries is community resource management (Kiss, 1990; Hannah, 1992; Wells et al., 1992; Bissonette and Krausman, 1995). Although all forest resources within the Ituri are under de jure control by the government, local households have de facto management authority. Direct local ownership of game is a fact in Ituri, but the following conditions are considered necessary for joint management of natural resources to result in wildlife conservation (Becker and Ostrom, 1995).

1 Accurate information about the condition of the resource and expected flow of benefits and costs are available at low cost.

2 Participants are relatively homogeneous in regard to asset structure, information and preferences.

3 Participants share a common understanding about potential benefits and risks associated with the continuance of the status quo as contrasted with changes in norms and rules that they could feasibly adopt.

4 Participants share generalized norms of reciprocity and trust that can be used as initial social capital.

5 The group using the resource is relatively small and stable.

6 Participants do not discount the future at a high rate.

7 Participants have the autonomy to make many of their own operational rules, which, if made legitimately, will be supported and potentially enforced by external authorities.

8 Participants use collective-choice rules that fall between the extremes of unanimity or control by a few (or even the bare minority), and thus they avoid high transaction or high deprivation costs.

9 Participants can develop relatively accurate and low-cost monitoring and sanctioning arrangements.

Unless communities exhibit these characteristics Becker and Ostrom (1995) believe that externalities will continue to exist, lowering the true value of forest resources, and resulting in their irrational overexploitation. Poverty and the absence of effective political or co-operative institutions above the household or clan level in Ituri forest communities make it highly unlikely that these prerequisites for community-based resource conservation could be met in the near future. Equally important, unless the local community of resource users can exclude outsiders from exploiting forest goods that are rival, then there is no constraint to the rate of resource appropriation exceeding the rate of regeneration. Indigenous communities are seldom large or politically powerful. It seems unlikely, therefore, that they will be able, at least initially, to control outsider access to 'their' resources by either military or political means. Yet, empowerment of local communities through the development and support of resource management consultation committees (Comités Permanent de 
Consultation Locale, CPCLs) around the OWR is showing encouraging signs in that some CPCLs are clearly concerned about, and are actively reporting, encroachment in 'their' forest by outsiders.

Although the newly established government of the Democratic Republic of Congo may formally devolve ownership and management rights to local communities, none of its public proclamations has demonstrated an intent to do so. Furthermore, the prerequisites for common-property resource management may not evolve within forest-dwelling communities before bushmeat consumption seriously depletes forest animal populations. If we are concerned about conservation of a globally scarce resource that is at present still relatively abundant locally, it is essential that research on bushmeat production and consumption is undertaken and that pilot smalllivestock production projects are supported to start the process of lowering household demand for bushmeat. Because local communities currently have de facto control over forest resources in the Ituri, it is exceedingly important they are involved in development and implementation of all policies associated with sustainable management of wild game in the OWR. Unless local communities are advocates for bushmeat management no command-andcontrol measure is likely to work, and demand-side approaches may be unacceptable or not considered worth adopting. Ignoring the human factor in the sustainable management of bushmeat is a clear recipe for failure (Stephenson and Newby, 1997).

Defaunation can occur far more rapidly and more 'invisibly' than deforestation, even in areas that are being selectively logged (Auzel, 1996; Wilkie et al., 1997b). If the north is really concerned about biodiversity conservation and thus willing to pay for wildlife management in the south, international conservation non-governmental organizations and bilateral donors must invest more in enhancing our understanding of the impact of hunting on forest fauna, and developing and implementing approaches to mitigate demand for bushmeat without jeopardizing human health and livelihood security.

\section{Acknowledgments}

Thanks to Lea Borkenhagen, Philippe Chardonnet, Cheryl Fimbel, John Hart, Terese Hart, John Robinson, Lee White and an anonymous referee for commenting on the manuscript. This study was supported by NSF Grants BNS-871-9575 and SBR940-2034, and funding from the Wildlife Conservation Society. We would also like to thank Conservateur Jean Nlamba of the Insititut Congolais pour la Conservation de la Nature, Karl Ruf of Gilman Investment Corporation and Pere Silvano Ruaro of the Catholic mission in Mambasa for their continuing support of our work in the Ituri.

\section{References}

Alvard, M.S. 1993. Testing the 'ecologically noble savage' hypothesis: interspecific prey choice by Piro hunters of Amazonian Peru. Human Ecology, 21, 355-387.

Alvard, M.S. 1994. Conservation by native peoples: prey choice in a depleted habitat. Human Nature, 5, 127-154.

Anadu, P.A., Elamah, P.O. and Oates, J.F. 1988. The bushmeat trade in southwestern Nigeria: a case study. Human Ecology, 16, 199-208.

Anstey, S. 1991. Wildlife utilization in Liberia. WWF International, Gland, Switzerland.

Asibey, E.O.A. 1974. The grasscutter, Thyronomys swinderianus Temmick, in Ghana. Symposium of the Zoological Society of London, 34, 161-170.

Asibey, E.O.A. 1977. Expected effects of land-use patterns on future supplies of bushmeat in Africa south of the Sahara. Environmental Conservation, 4 , 43-49.

Auzel, P. 1996. Evaluation de l'impact de la chasse sur la faune des forêts d'Afrique Centrale, Nord Congo. Mise au point de méthodes basées sur l'analyse des pratiques et les résultats des chasseurs locaux. Wildlife Conservation Society/GEF Congo, Bomassa, Republic of Congo.

Bailey, R.C. and Peacock, N.R. 1988. Efe pygmies of northeast Zaire: subsistence strategies in the Ituri forest. In Uncertainty in the Food Supply (eds I. de Garine and G. A. Harrison), pp. 88-117. Cambridge University Press, Cambridge.

Barnes, R.F.W. 1990. Deforestation trends in tropical Africa. African Journal of Ecology, 28, 161-173.

Becker, D.S. and Ostrom, E. 1995. Human ecology and resource sustainability: the importance of institutional diversity. Annual Review of Ecology and Systematics, 26, 113-133.

Behra, O. 1989. Sex ratio of African dwarf crocodiles (Osteolaemus tetraspis Cope, 1861) exploited for food in Congo. Musee National d'Histoire Naturelle, Paris, France. 
Bennett Hennessey, A. 1995. A study of the meat trade in Ouesso, Republic of Congo. Wildlife Conservation Society, Bronx, NY.

Bishop, C.A. 1972. Demography, ecology and trade among the northern Ojibwa and swampy Cree. Western Canadian Journal of Anthropology, 3 (1), 58-71.

Bissonette, J.A. and Krausman, P.R. 1995. Integrating people and Wildlife for a Sustainable Future. The Wildlife Society, Bethesda, Maryland.

Bodmer, R.E. 1995. Susceptibility of mammals to overhunting in Amazonia. In Integrating People and Wildlife for a Sustainable Future (eds J.A. Bissonette and P. R. Krausman), pp. 292-295. The Wildlife Society, Bethesda, Maryland.

Caldecott, J. 1987. Hunting and Wildlife Management in Sarawak. World Wildlife Fund, Washington, DC.

Chardonnet, P., Fritz, H., Zorzi, N. and Feron, E. 1995. Current importance of traditional hunting and major contrasts in wild meat consumption in sub-saharan Africa. In Integrating People and Wildlife for a Sustainable Future (eds J. A. Bissonette and P. R. Krausman), pp. 304-307. The Wildlife Society, Bethesda, Maryland.

Chestin, I.E. and Poyarkov, A.Y. 1995. Preliminary data on the illegal wildlife trade in Russia. In Integrating People and Wildlife for a Sustainable Future (eds. J. A. Bissonette and P. R. Krausman), pp. 323-325. The Wildlife Society, Bethesda, Maryland.

Curran, B. and Tshombe, R. 1997. Integrating local communities into the management of protected areas: lessons from Zaire and Cameroon. In African Rain Forest Ecology and Conservation (eds W. Weber, A. Veder, H. Simons Morland, L. White and T.Hart). Yale University Press, New Haven. In press.

Fa, J.E., Juste, J., Perez del Val, J. and Castroviejo, J. 1995. Impact of market hunting on mammal species in Equatorial Guinea. Conservation Biology, 9, 1107-1115.

Fitzgibbon, C.D., Mogaka, H. and Fanshawe, J.H. 1995. Subsistence hunting in Arabuko-Sokoke forest, Kenya, and its effects on mammal populations. Conservation Biology, 9, 1116-1126.

Fragoso, J.M.V. 1991. The effects of hunting on tapirs in Belize. In Neotropical Wildlife Use and Conservation (eds J.G. Robinson and K.H. Redford), pp. 154-162. University of Chicago Press, Chicago.

Geist, V. 1988. How markets for wildlife meat and parts, and the sale of hunting privileges, jeopardize wildlife conservation. Conseroation Biology, 2, 15-26.

Hannah, L. 1992. African people, African parks: an evaluation of development initiatives as a means of improv- ing protected area conservation in Africa. Conservation International, Washington, DC.

Harako, R. 1976. The Mbuti as hunters, a study of ecological anthropology of the Mbuti pygmies. Kyoto University African Studies, 10, 37-99.

Hart, J.A. 1985. Comparative dietary ecology of a community of frugivorous forest ungulates in Zaire. $\mathrm{PhD}$ thesis, Michigan State University, East Lansing.

Hart, J.A. and Petrides, G.A. 1987. A study of relationships between Mbuti hunting systems and faunal resources in the Ituri Forest of Zaire. In People and the Tropical Forest (eds A. E. Lugo, J. Ewel, S. Hecht, P. Murphy, C. Padoch, M. Schmink and D. Stone), pp. 12-15. US Department of State, US Man and Biosphere Program, Washington, DC.

HPI. 1996a. Boyo rural integrated farmer's alliance, Cameroon: project summary. Heifer Project International, Little Rock, Arkansas.

HPI. 1996b. Bui North/Donga Mantung small-holder integrated agricultural projects, Cameroon: project summary. Heifer Project International, Little Rock, Arkansas.

Hudson, C.M., Jr. 1995. Why the southeastern Indians slaughtered deer. In Indians, Animals and the Fur Trade: a Critique of Keepers of the Game (ed. S. I. Krech), pp. 157-176. University of Georgia Press, Athens.

Ichikawa, M. 1983. An examination of the hunting dependent life of the Mbuti pygmies, eastern Zaire. African Studies Monographs, 4, 55-76.

IFPF. 1995. Annual Report. Ituri Forest Peoples Fund, Newton, Massachusetts.

Joanen, T., McNease, L., Elsey, R. and Staton, M.A. 1994. The commercial consumptive use of the American alligator (Alligator mississippiensis) in Louisiana: its effect on conservation - a case study. Rockefeller Wildlife Refuge, Grand Chenier, Louisiana.

Jori, F., Mensah, G.H. and Adjamohoun, E. 1995. Grasscutter production: an example of rational exploitation of wildlife. Biodiversity and Conservation, 4, 257-265.

Juste, J., Fa, J.E., Perez del Val, J. and Castroviejo, J. 1995. Market dynamics of bushmeat species in Equatorial Guinea. Journal of Applied Ecology, 32, 454-467.

Kiss, A. 1990. Living with wildlife: wildlife resource management with local participation in Africa. Technical Paper No. 130. World Bank, Washington, DC.

Lahm, S.A. 1993. Ecology and economics of human/wildlife interaction in northeastern Gabon. PhD thesis, New York University, New York.

Lamarque, F.A. 1995. The French co-operation's strategy in the field of African wildlife. In Integrating people and Wildlife for a Sustainable 
Future (eds J. A. Bissonette and P. R. Krausman), pp. 267-270. The Wildlife Society, Bethesda, Maryland.

Ludwig, D., Hilborn, R. and Walters, C.J. 1993. Uncertainty, resource exploitation and conservation: lessons from history. Science, 260, 17-36.

ma Mbalele, M. 1978. Part of African culture. Unasylva, 29, 16-17.

Martin, G.H.G. 1983. Bushmeat in Nigeria as a natural resource with environmental implications. Environmental Conservation, 10, 125-134.

Muchaal, P.K. and Ngandjui, G. 1995. Wildlife populations in the western Dja reserve (Cameroon): an assessment of the impact of village hunting and alternatives for sustainable utilization. ECOFAC/ MEF, Yaounde, Cameroon.

Myers, N. 1980. Conversion of Tropical Moist Forests. National Academy of Sciences, Washington, DC.

Njiforti, H.L. 1996. Preferences and present demand for bushmeat in northern Cameroon: some implications for wildlife conservation. Environmental Conservation, 23, 149-155.

Noss, A.J. 1995. Duikers, cables and nets: a cultural ecology of hunting in a central African forest. PhD thesis, University of Florida, Gainesville.

Rich, E.E. 1960. Trade habits and economic motivation among the indians of north America. Canadian Journal of Economics and Political Science, 26, 35-53.

Robinson, J.G. and Redford, K.H. 1991. Sustainable harvest of neotropical forest mammals. In Neotropical Wildlife Use and Conservation (eds J. G. Robinson and K.H. Redford), pp. 415-429. University of Chicago Press, Chicago.

Steel, E.A. 1994. Study of the value and volume of bushmeat commerce in Gabon. World Wildlife Fund, Libreville.

Stephenson, P.J. and Newby, J.E. 1997. Conservation of the Okapi Wildlife Reserve, Zaire. Oryx, 31, 49-58.

Tewe, G.O. and Ajaji, S.S. 1982. Performance and nutritional utilization by the African giant rat (Cricetomys gambianus, W.) on household waste of local foodstuffs. African Journal of Ecology, 20, $37-41$.

Thomas, S. 1991. Population densities and patterns of habitat use among anthropoid primates of the Ituri Forest, Zaire. Biotropica, 23, 68-83.

Trefethen, J.B. 1975. An American Crusade for Wildlife. Winchester Press and the Boone and Crockett Club, New York.

Wells, M., Brandon, K. and Hannah, L. 1992. People and parks: linking protected area management with local communities. The World Bank, Washington, DC.

White, L.J.T. 1994. Biomass of rain forest mammals in the Lope reserve, Gabon. Journal of Animal Ecology, 63, 499-512.

Wilkie, D.S. 1989. Impact of roadside agriculture on subsistence hunting in the Ituri forest of northeastern Zaire. American Journal of Physical Anthropology, 78, 485-494.

Wilkie, D.S. 1990. Establishing the Okapi Rain Forest Reserve: avoiding human land-use conflicts using satellite image analysis. Presented at the 10th Annual International Geoscience and Remote Sensing Symposium, College Park, MD.

Wilkie, D.S. and Curran, B. 1991. Why do Mbuti hunters use nets? Ungulate hunting efficiency of bows and nets in the Ituri rain forest. American Anthropologist, 93, 680-689.

Wilkie, D.S. and Curran, B. 1993. Historical trends in forager and farmer exchange in the Ituri rain forest of northeastern Zaire. Human Ecology, 2, 389-417.

Wilkie, D.S. and Finn, J.T. 1988. A spatial model of land use and forest regeneration in the Ituri forest of northeastern Zaire. Ecological Modelling, 41, 307-323.

Wilkie, D.S. and Finn, J.T. 1990. Slash-burn cultivation and mammal abundance in the Ituri forest, Zaire. Biotropica, 22, 90-99.

Wilkie, D.S. and Morelli, G.A. 1997. Roads and development in eastern Congo: declining livelihoods and growing self-reliance among the Lese and Efe. Cultural Survival Quarterly, 21, 38-41.

Wilkie, D.S., Curran, B., Tshombe, R. and Morelli, G.A. 1997a. Modeling the sustainability of subsistence farming and hunting in the Ituri Forest of Zaire. Conservation Biology, in press.

Wilkie, D.S., Sidle, J.G., Boundzanga, G.C., Blake, S. and Auzel, P. 1997b. Defaunation or deforestation: commercial logging and market hunting in northern Congo. In The Impacts of Commercial Logging on Wildlife in Tropical Forests (eds A. Grajal, J. G. Robinson and A. Vedder). In press.

David S. Wilkie, Associates in Forest Research and Development, 18 Clark Lane, Waltham, MA 021541823, USA. E-mail: dwilkie@msn.com

Bryan Curran, Wildlife Conservation Society, 185th and Southern Blvd, Bronx, NY 10460, USA. Richard Tshombe, Wildlife Conservation Society, 185th and Southern Blvd, Bronx, NY 10460, USA.

Gilda A. Morelli, Department of Psychology, Boston College, Chestnut Hill, MA 02167-3807, USA.

Received 10 March 1997

Accepted 24 October 1997 